\begin{tabular}{ll}
\hline POLITEIA & POLITEIA: Jurnal Ilmu Politik \\
Politeia: Jurnal Ilmu Politik 12 (1) (2020): 41-48 \\
ISSN 0216-9290 (Print), ISSN 2549-175X (Online) \\
Available online https://iurnal.usu.ac.id/index.php/politeia
\end{tabular}

\title{
Dampak Kegagalan Kudeta Militer Turki Tahun 2016 Terhadap Politik di Turki
}

\author{
Sri Kurnia Sari* \& A Arifin \\ Departemen Ilmu Politik Fakultas Ilmu Sosial dan Ilmu Politik Universitas Sumatera \\ Utara, Indonesia
}

\begin{abstract}
Abstrak
Pada 15 Juli 2016, terjadi sebuah peristiwa Kudeta Militer di Turki untuk menggulingkan pemerintahan Presiden Recep Tayyip Erdogan. Walaupun kudeta tersebut gagal, tentu bukan suatu keuntungan bagi Turki, yang mana pemerintah tengah berupaya meningkatkan kestabilan politik, ekonomi dan sosial di Turki. Tulisan ini mengkaji bagaimana dampak kudeta militer Turki tahun 2016 terhadap politik Turki dengan memusatkan kajian dampaknya terhadap politik domestik di Turki. Pendekatan dalam penelitian menggunakan kajian pustaka, Teknik pengumpulan data penelitian ini adalah dengan studi pustaka menggunakan data sekunder dengan analisis deskriptif. Hasil penelitian ini mendeskripsikan bahwa secara politik domestik, kudeta tersebut berdampak pada hubungan pemerintah dengan partai oposisi, iklim demokrasi, kebijakan politik dan birokrasi militer.
\end{abstract}

Kata Kunci: Adelet ve Kalkina Partisi (AKP), Angkatan Bersenjata Turki, Kudeta Militer, Politik Domestik

\begin{abstract}
On July 15th 2016, a military coup in Turkey happened that wanted to overthrow President Recep Tayyip Erdogan. Although its failed, certainly its unexpected which is Turkish government trying to increase their political, economic and social stability in Turkey. This research describes the impact of the 2016 Turkish military coup on Turkish politics by focusing on its impact on domestic politics in Turkey. The data collection technique of this research is literature study using secondary data with descriptive analysis. This research describes that the coup had an impact on domestic politics in Turkey : the government's relationship with the opposition party, the democratic climate, political policy and military bureaucracy.
\end{abstract}

Password: Adelet ve Kalkina Partisi (AKP), Domestic Politics, Military Coup, Turkish Armed Forces

How to Cite: Sari, S Kurnia. (2019). Dampak Kegagalan Kudeta Militer Turki 2016 terhadap Politik di Turki, Politeia: Jurnal Ilmu Politik, 12 (1): 41-48

\footnotetext{
${ }^{*}$ Corresponding author:

E-mail: kurniaram7@gmail.com
} 


\section{PENDAHULUAN}

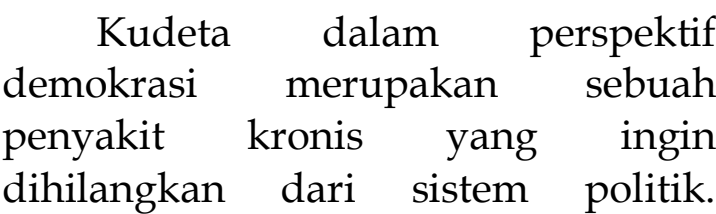
Demokrasi sebagai sebuah mekanisme politik menghendaki proses transformasi kekuasaan yang dilakukan melalui proses politik yang tidak mempergunakan instrumen kekuasaan. Sehingga apapun alasan di balik kudeta, baik yang klise seperti demi kesejahteraan umum, penegakan hukum dan alasan lainnya, ditolak keberadaannya. Sebagaimana yang diungkapkan Nordlinger bahwa kudeta sebagai bagian dari proses politik. Menurutnya, kudeta merupakan sebuah kunci bagi seorang perwira militer untuk dapat mengambil alih kekuasaan negara yang kemudian peristiwa kudeta itu disebut kudeta militer. Hal ini biasanya dilakukan berdasarkan keadaan negara yang situasinya memburuk dari sisi ekonomi dan politik, misalnya korupsi oleh pejabat negara, aktor-aktor separatisme, kenaikan tingkat inflasi, tingkat pengangguran yang naik, dan lainlain. Biasanya, kudeta militer ini digunakan ketika muncul ketidakpercayaan lagi terhadap pemerintah yang sedang berkuasa dan berlaku tidak taat (Nordlinger 1994 : 60).

Hampir sebagian besar negara telah merasakan peristiwa politik tersebut, baik yang berhasil maupun tidak berhasil. Sebuah negara yang mengalami kudeta dapat dikatakan telah memiliki esensi pengalaman dan proses bernegara tersendiri dibandingkan dengan peristiwaperistiwa politik lainnya.
Begitu juga dengan Turki, proses bernegara yang dialami Turki tentu banyak sekali terjadi perubahan dan perkembangan. Selain adanya perkembangan dan perubahan demi perubahan, juga diwarnai dengan gejolak, baik dari segi masyarakat, ekonomi, dan khususnya dalam proses politik. Turki, paling tidak sudah sering mengalami kudeta sejak Turki menyandang status sebagai negara Republik Turki yang mana dari keseluruhan kudeta tersebut juga melibatkan elit dan pejabat tinggi militer Turki (Turk Silalhli Kuvvetleri/Angkatan Bersenjata Turki/TSK) (Alfian, $2018: 2$ ).

Pada 15 Juli 2016 terjadi upaya kudeta militer yang bertujuan menumbangkan rezim Erdogan yang tengah memegang kendali kekuasaan. Pelaku kudeta mengklaim telah sepenuhnya mengambil alih administrasi negara untuk mengembalikan tatanan konstitusional, hak asasi manusia dan kebebasan, aturan hukum dan keamanan umum yang yang buruk di bawah Pemerintahan Erdogan. Para pelaku kudeta mengebom gedung lembaga-lembaga penting negara, seperti Gedung Parlemen, Istana Beylerbeyi (Istana Kepresidenan), Balai Staf Umum, markas Besar Polisi dan markas Organisasi Intelijen Nasional (MIT) dengan helikopter dan pesawat F-16. Bersamaan dengan institusiinstitusi yang memiliki nilai strategis ini, 241 warga sipil yang menentang para pelaku kudeta terbunuh dan 2.195 terluka akibat pengeboman. Begitu juga di wilayah Istanbul, tank memblok lalulintas di jembatan Bogazici (Boshporus) dan mengepung Bandara Attarturk serta menguasai 
menara kontrol bandara (Kuncahyono, 2018 : 218).

Meskipun kudeta tersebut gagal, tentu peristiwa ini bukanlah suatu yang menguntungkan bagi Turki ditengah-tengah pemerintah berupaya meningkatkan kestabilan politik, ekonomi dan sosial di Turki.

Tujuan dalam penelitian ini, yaitu bagaimana dampak dari peristiwa Kudeta Militer 2016 Turki terhadap politik di Turki. ?. Untuk diketahui juga bahwa interval waktu yang menjadi parameter penelitian yaitu dari tahun 2016-2017.

\section{METODE PENELITIAN}

Adapun metode penelitian yang digunakan penulis dalam penelitian ini adalah studi pustaka menggunakan data sekunder dengan 2 (dua) pendekatan. Pertama, dimulai dengan pertanyaan penelitian (rumusan masalah) kemudian dilanjutkan dengan mengumpulkan data yang relevan. Kemudian, menelaahnya untuk mencermati variabel-variabel (aspek-aspek) apa saja yang ada dalam data tersebut untuk kemudian dimunculkan pertanyaan penelitian (rumusan masalahnya) dengan menghubunghubungkan berbagai aspek (variabel) tersebut (Andrews, 2012 : 10).

\section{HASIL DAN PEMBAHASAN}

Perlu diketahui bahwa dampak yang ditimbulkan terhadap politik maupun ekonomi Turki adalah tidak hanya disebabkan oleh kudeta semata. Dalam artian bahwa pada waktu itu Turki sedang menghadapi situasi seperti serangan teroris, embargo ekonomi, perang dagang Amerika Serikat dan lainya.
Kudeta militer 2016 memberikan dampak terhadap politik domestik di Turki. Pertama, kudeta tersebut mempengaruhi hubungan pemerintah dengan partai-partai oposisi. Setelah kudeta, pemerintah Turki (dalam hal ini Adelet ve Kalkina Partisi/AKP) mulai untuk berkumpul dengan pihak-pihak yang berseberangan, memberikan mereka informasi dan mempertimbangkan saran mereka.

$$
\text { Adanya pendekatan yang }
$$
dilakukan di antara pihak-pihak yang berseberangan (oposisi), seperti Cumhuriyet Halk Partisi (Partai Rakyat Republik/CHP), Milliyetci Hareket Partisi (Partai Pergerakan Nasionalis/MHP) dan Halklarin Demokratik Partisi (Partai Demokrat Rakyat/HDP). Cumhuriyet Halk Partisi (Partai Rakyat Republik/CHP) menentang kudeta tersebut melalui pemimpinnya Kemal Kilicdaroglu yang secara terbuka menyatakan hal ini pada malam kudeta. Kilicdaroglu juga berpartisipasi dalam konsolidasi pasca kudeta pada 7 Agustus di Istanbul dengan lebih dari 5 juta partisipan, serta memberikan pidatonya. Begitu juga dengan Halklarin Demokratik Partisi (Partai Demokrat Rakyat/HDP), yang proKurdi menyuarakan sikap kerasnya terhadap kudeta (Ataman, 2017 : 56).

Akan tetapi, hubungan Adelet ve Kalkina Partisi/AKP) dengan oposisi terlihat berbeda ketika wacana Referendum Konstitusi kembali menjadi topik di forum-forum pemerintahan Turki. Beberapa bulan setelah terjadinya peristiwa kudeta, pemerintah Turki menyetujui adanya perubahan konstitusi yang mengatur sistem pemerintahan yang ada di Turki. Poin utama dari perubahan konstitusi tersebut adalah perubahan 
sistem pemerintahan dari yang sebelumnya sistem pemerintahan parlementer menjadi sistem presidensial. Adapun tujuan dari perubahan sistem pemerintahan tersebut untuk memperkuat posisi badan eksekutif apabila situasi politik dalam negeri tidak stabil. Upaya perubahan konstitusi tersebut kemudian direalisasikan dalam referendum konstitusional pada bulan April 2017. Berdasarkan laporan yang dihimpun dari Turkish Radio and Television hasil voting referendum tersebut $51,41 \%$ pemilih menyatakan persetujuannya atas perubahan konstitusi (TRT, $2018:$ 12).

Beberapa pihak yang menentang perubahan konstitusi tersebut terutama pihak oposisi yang diwakili oleh Partai Rakyat Republik (Cumhuriyet Halk Partisi/CHP) dan Partai Halklarin Demokratik Partisi (Partai Demokrat Rakyat/HDP) dari golongan etnis Kurdi. Menurut pihak oposisi tersebut, perubahan konstitusi dalam hal ini sistem pemerintahan akan mengakibatkan pemerintahan yang sedang berjalan mengarah kepada sistem otoritarian. Hal tersebut disebabkan adanya poin-poin dalam konstitusi baru tersebut yang dianggap memberi hak istimewa terhadap presiden untuk memiliki wewenang penuh dalam menjalankan pemerintahan.

Kedua, kudeta tersebut memberikan pengaruh baik bagi demokrasi Turki. Berdasarkan keterangan sebelumnya, adanya kondsolidasi dan sebagainya pada 7 Agustus 2016 mencerminkan nilai solidaritas dari setiap elemen politik Turki. Solidaritas inilah yang memainkan peran penting dalam kegagalan kudeta dan berkontribusi memperkuat budaya politik demokratis Turki. Alasannya adalah masyarakat sipil, baik politisi maupun rakyat umumnya telah memiliki pengalaman kudeta sebelumnya, sehingga mereka akan dengan mudah dan dengan berani melawan pihak yang mencoba merusak iklim demokrasi. Tentunya dengan pegalaman tersebut, mereka mempunyai pengetahuan lebih tentang bagaimana melawan kudeta dengan atau tanpa senjata.

Kudeta Militer 15 Juli 2016, juga meningkatkan budaya dan perilaku dalam masyarakat. Ada perbedaan antara menentang pemerintah yang berkuasa dan menentang Turki. Pelaku Kudeta tidak hanya menentang pemerintah, dalam hal ini pelaku kudeta juga menentang Turki. Sebagian besar masyarakat Turki masih bersiaga untuk mencegah upaya lanjutan dari kudeta tersebut. Sikap bersatu dari rakyat Turki dan semua partai politik menentang kudeta tersebut serta keputusan presiden Erdogan mengajak partaipartai oposisi merupakan perkembangan baik bagi negara Turki yang telah sangat terpolarisasi dalam beberapa tahun terakhir. Tampaknya jelas bahwa kepekaan terhadap demokrasi di masyarakat menguat pasca kudeta.

Ketiga, kudeta tersebut juga sangat memberi pengaruh terhadap kebijakan politik yang diberlakukan oleh pemerintah Turki. Pasca kudeta, Turki berada pada status Kondisi Negara Darurat yang diberlakukan selama 3 bulan. Kebijakan ini mengandung arti bahwa selama masa darurat, pemerintah khususnya Presiden, memiliki kekuasaan di parlemen untuk memberlakukan 
undang-undang baru dan membatasi atau meniadakan hak dan kebebasan rakyat. Tidak hanya terjadi di pemerintahan pusat saja, tetapi juga pemerintahan provinsi. Termasuk mengakhiri peran militer dalam politik (Constitution of the Republic of Turkey, 2017 : 50)

Kebijakan lainnya yang diterapkan Presiden Erdogan dan Adelet ve Kalkina Partisi/AKP) pasca kudeta adalah melakukan sejumlah langkah penindakan refresif terhadap pelaku kudeta maupun berbagai pihak yang terlibat. Bisa dikatakan kebijakan pembersihan yang dilakukan oleh pemerintah menimbulkan pertanyaan terkait pengaruh dari pembersihan ini. Dalam beberapa minggu terakhir pasca kudeta, puluhan ribu orang ditahan atau kehilangan pekerjaan karena dugaan afiliasi mereka dengan Gerakan Gulen. Namun, karena struktur organisasi gerakan yang masih dianggap belum jelas, tidak mudah untuk menentukan siapa yang seorang Gulenist dengan yang bukan.

Menurut data Kementerian Dalam Negeri Turki menangguhkan 8.777 pejabat, termasuk 7.899 petugas polisi, 30 gubernur 614 petugas Gendarmerie (Pasukan Umum yang bertanggung jawab atas ketertiban umum) dan 47 gubernur distrik. Sebanyak 2.745 hakim dan 5 anggota Mahkamah Agung Turki (Hakimler ve Savcilar Yuksek Kurulu/HSYK) dipecat oleh otoritas terkait, sedangkan 2.836 anggota militer termasuk dari perwira tinggi ditahan pada 16 Juli 2016, 7.543 orang ditahan karena diduga berperan dalam kudeta terdiri dari 100 polisi, 6.038 tentara, 755 hakim, dan 650 masyarakat sipil. Selain itu, di bidang pendidikan ada 15.200 staf
Kementerian Pendidikan yang dipecat dan 21.000 guru ditarik izin mengajarnya. Jumlah tersebut terus meningkat hingga 9 Desember 2016, ketika tercatat bahwa:

1. Lebih dari 125.000 pekerja dipecat

2. Sebanyak 92.607 kasus hukum diproses, 39.378 di antaranya telah ditahan;

3. Total 3.673 hakim dan jaksa dipecat dan 2.700 lainnya diberikan sanksi;

4. Sekitar 1.800 organisasi/ yayasan ditutup

5. Sekitar 2.100 sekolah, asrama, dan universitas ditutup (Korkmaz, 2016).

Meskipun pihak oposisi menyetujui kebijakan demi kebijakan yang diambil pemerintah saat itu, akan tetapi pihak oposisi khawatir bahwa pembersihan dan status darurat dapat berubah menjadi penangkapan yang menargetkan semua elemen termasuk pengkritik yang bukan dari bagian terkait kudeta. Namun, pemerintah mengklaim bahwa kebijakan tersebut hanya akan digunakan untuk menjaring Gulenist di dalam birokrasi negara.

Keempat, Kudeta Militer tersebut sangat memberikan dampak yang signifikan terhadap birokrasi pemerintahan. Banyaknya penahanan dan penangkapan telah merambah ke institusi penting lainnya. Yang paling ramai adalah pembersihan di lembaga-lembaga keamanan nasional. Ribuan pejabat militer termasuk jenderal, serta kepolisian ditangkap. Pembersihan ini akan menciptakan kekosongan jabatan dalam institusi 
keamanan pada saat itu Turki sedang gencar-gencarnya menghadapi beberapa tantangan keamanan nasional di dalam negeri dan di kawasan. Oleh sebab itu, pada bulanbulan berikutnya, penunjukan untuk mengisi posisi yang kosong di birokrasi negara dan aparat keamanan, pemerintah melakukan restrukturisasi terhadap intansi militernya.

Restrukturisasi

Angkatan

Bersenjata Turki (Turk Silahli Kuvvetleri/TSK) berlangsung dengan cepat sejak upaya kudeta. Berikut ini beberapa poin penting dari perubahan struktur hingga operasional Angkatan Bersenjata Turki (TSK) pasca kudeta militer

1. Personil dan staf Kementerian Pertahanan Nasional Turki berasal dari warga sipil yang sebelumnya berasal dari internal militer.

2. Angkatan Darat, Angkatan Laut dan Angkatan Udara terhubung langsung ke Kementerian Pertahanan Nasional Turki. Sebelumnya berada dibawah komando Angkatan Bersenjata Turki (TSK).

3. Presiden dan Perdana Menteri (sebelum referendum 2017) memiliki wewenang untuk menerima informasi langsung dari/dan untuk mengeluarkan perintah langsung ke komandan angakatan darat, udara, dan laut.

4. Seluruh kontrol fasilitas industri ditransfer ke
Kementerian Dalam Negeri Turki.

5. Prosedur disiplin dan urusan pribadi para hakim militer telah dialihkan kepada Kementerian Dalam Negeri Turki.

6. Dewan Militer Tertinggi (Supreme Military Council) lebih diperluas termasuk Perdana Menteri dan Pengadilan Nasional, Menteri Luar Negeri, dan Mendetri Dalam Negeri

7. Semua akademi militer akan ditutup dalam waktu dua tahun.

8. Universitas Pertahanan Nasional (NDU) di bawah kontrol Menteri Dalam Negeri untuk melatih para perwira angkatan darat.

9. Restrukturisasi proses untuk penunjukan pasukan Angkatan Bersenjata Turki (TSK), sistem promosi, tugas dan wewenang elit melalui aturan tertentu.

10. Semua rumah sakit militer di bawah wewenang Kementerian Kesehatan bukan militer.

11. Komando Gendarmerie dan Komando Penjaga Pantai dikendalikan oleh (Turk Silahli Kuvvetleri/TSK), untuk personel, pelatihan sepenuhnya menjadi bagian dari urusan Kementerian Dalam Negeri.

12. Barak militer berada di kota metropolitan yang strategis, seperti istanbul dan Ankara, 
telah dipindahkan ke luar batas kota.

13. Lulusan Sekolah Tinggi Agama dan Kejuruan dapat mendaftar di akademi militer (Ataman, 2017 : 181-182).

Berdasarkan 13 (tiga belas) poin penting terkait restrukturisasi militer diatas, pada akhirnya tampak bahwa Presiden Erdogan memutuskan kebijakan yang ekstrim terhadap militer untuk mengembalikan konteks militer ke barak. Seorang ahli hubungan sipil-militer Jerman Lars Haugom mengatakan bahwa terdapat peningkatan kontrol pemerintahan sipil terhadap Angkatan Bersenjata Turki (Turk Silahli Kuvvetler/TSK) pasca kudeta terjadi. Bahkan memposisikan lembaga Militer di bawah Kementerian Dalam Negeri Turki. Jika diperhatikan militer bukan lagi lembaga yang independen seperti sebelumnya. Kepala Pertahanan Nasional Turki secara langsung ditunjuk oleh presiden serta Staf Umum akan dialihkan ke Departemen Pertahanan (Haugom, 2016: 6).

Selain itu, presiden akan dapat memberikan perintah langsung kepada komandan pasukan darat, udara, dan laut Turki tanpa harus melalui pengwasan atau otoritas lain. Hal ini terjadi pada kasus penunjukan Jenderal Hulusi Akar untuk jabatan Menteri Pertahanan Nasional (Cengiz, 2018).

Terlepas dari hal tersebut, sistem pendidikan militer juga mengalami perubahan besar. Sekolah militer sudah ditutup, dan akademi militer menjadi Universitas Pertahanan Nasional yang baru di bawah Kementerian Pertahanan Nasional. Rasionalistasnya adalah untuk mengubah Angkatan Bersenjata Turki (Turk Silahli Kuvvetleri/TSK). menjadi lembaga pertahanan yang lebih terkelola dan terkontrol yang mampu menangani tantangan keamanan Turki saat ini dan masa depan, tanpa menjadi ancaman untuk pemerintah sipil. Namun, dalam jangka panjang lembaga (Turk Silahli Kuvvetleri/TSK) berisiko menjadi lembaga yang cendereung terpolitisasi kedepannya. Kemudian, begitu juga posisi dari pasukan Gendarmerie (Pasukan Umum yang bertanggung jawab atas pemeliharaan keselamatan dan ketertiban umum) dan Coast Guardian Command (Pasukan Penjaga Pantai) sepenuhnya dialihkan ke Kementerian Dalam Negeri. Tampak jelas bahwa Pemerintah Adelet ve Kalkina Partisi/AKP) berusaha untuk meningkatkan kontrol sipil dan pengawasan terhadap Angkatan Bersenjata Turki.

\section{SIMPULAN}

Hasil analisis dampak kudeta Militer Turki tahun 2016 terhadap bidang politik domestik mendeskripsikan bahwa kudeta tersebut memberikan 4 dampak bagi perpolitikan di Turki. Pertama, hubungan Pemerintah dengan partaipartai oposisi. Kedua, budaya politik demokratis Turki. Ketiga, kebijakan politik dalam negeri dan keempat yaitu birokrasi militer.

\section{DAFTAR PUSTAKA}

Alfian, A., (2015). Militer dan Politik di Turki: Pergeseran Politik dan Terpinggirnya Militer Pasca AKP. Bekasi: Penjuru Ilmu Sejati. Andrews L., (2012). Classic Grounded Theory to Analyze Secondary Data: Reality and Reflections. Junal The 
Grounded Theory Review. Volume 11, Issue 1.

Ataman, M., (2017). July 15 Coup Attempt in Turkey: Context, Causes and Consequences. Istanbul: SETA Publications. Diunduh di https://setav.org/en/assets/upl oads/2017/07/July15Book.pdf pada 10 Maret 2019.

Cengiz, S., (2018). Turkey : Erdogans Appoinment of Army Chief as Defense Minister is Significant. Eurasia News and Analysis. Diunduh melalui https:/ / www.eurasiareview.co m/14072017-turkey-erdogansappointment-of-army-chief-asdefense-minister-is-significantoped/ pada tanggal 20 September 2019.

Haugom, L., (2016). Turkey After The Coup Attempt. Insights the Norwegian Institute for Defence Studies 4 (IFS). Dinduh di https://fhs.brage.unit.no/fhsxmlui/bitstream/handle/11250/ 2424945/IFS_Insights_4_2016_H augom.pdf pada tanggal 20 September 2019.

Korkmaz, O., (2016). Interior Ministry Suspends 8,777 Officials After Turkey's Failed Coup Attempt. Hurriyet Daily News. Diakses melalui http://www.hurriyetdailynews. com/interior-ministry-suspends8777-officials-after-turkeysfailed-coup-attempt-101737 pada tanggal 20 September 2019.

Kuncahyono, T., (2018). Turki: Revolusi Tak Pernah Henti. Jakarta: Kompas Media Nusantara.

The Grand National Assambly of Turkey. (2017). Constitution of the Republic of Turkey. Diunduh di https://global.tbmm.gov.tr/doc s/constitution_en.pdf pada tanggal 1 Sepetember 2019.

Turkish Radio \& Television., (2018). Turkey's Election 2018 (Trt World Research Centre May 2018). Diakses melalui https://www.trtworld.com/elec tions/files/turkeys-election2018-report.pdf pada tanggal 11 Maret 2019. 